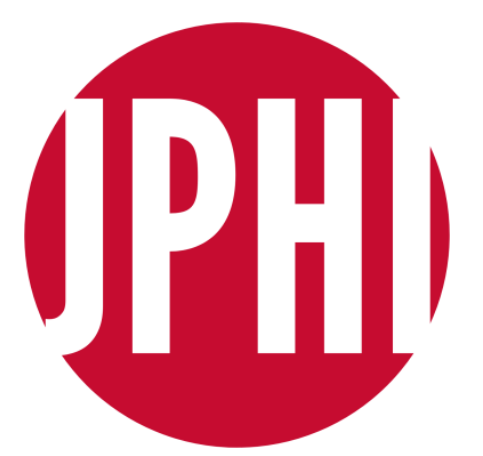

Jurnal Penegakan Hukum Indonesia (JPHI)

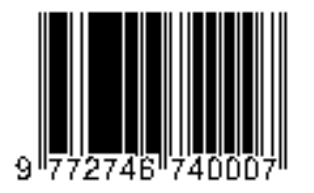

E-ISSN: 2746-7406

\section{PROBLEMATIKA TERHADAP BATAS WAKTU PERLINDUNGAN SAKSI OLEH LPSK DALAM PERKARA PIDANA}

\author{
M Ghazali Rahman \\ Fakultas Hukum, Universitas Lambung Mangkurat \\ Jl. Brigjen Hasan Basri, Kota Banjarmasin, Provinsi \\ Kalimantan Selatan (70123), Indonesia \\ Email: ghazalirahman@gmail.com
}

\begin{tabular}{|c|c|c|}
\hline \multicolumn{2}{|c|}{$\begin{array}{ll}\text { Submitted } & : 1908 / 2021 \\
\text { Revised } & : 20 / 09 / 2021 \\
\text { Accepted } & : 15 / 10 / 2021 \\
\text { Published } & : 18 / 10 / 2021\end{array}$} & \\
\hline \multicolumn{2}{|c|}{$\begin{array}{l}\text { Editorial Office: } \\
\text { Jl. Brigjen H. Hasan Basri } \\
\text { Komplek Polsek Banjarmasin } \\
\text { Utara Jalur 3, No. } 9 \text { Kota } \\
\text { Banjarmasin; Provinsi } \\
\text { Kalimantan Selatan; Republik } \\
\text { Indonesia (70125). } \\
\text { Email } \\
\text { jphi.scholarcenter@gmail.com } \\
\text { Principal Contact } \\
\text { +62 } 82157709493\end{array}$} & $\begin{array}{l}\text { This study aims to determine the time limit of protection provided by } \\
\text { LPSK clearly to witnesses who are undergoing the examination process } \\
\text { and also to find out whether LPSK has provided protection in } \\
\text { accordance with what is currently in effect. The type of research used } \\
\text { is normative legal research, namely research to obtain legal materials } \\
\text { by analyzing and collecting legal materials related to the issues } \\
\text { discussed. (1) The protection efforts that will be given to witnesses } \\
\text { regarding a limit on when the protection starts and ends of witness } \\
\text { protection by LPSK must be optimized so that witnesses who give their } \\
\text { statements in order to seek a truth are deemed necessary to clearly } \\
\text { pay attention to the time limit for witness protection. (2) Law No. } 31 \\
\text { of } 2014 \text { on LPSK, especially regarding the time limit for protection, is } \\
\text { still considered not maximal and is considered not sufficient to } \\
\text { guarantee the witness's sense of trust in LPSK. Weaknesses like this } \\
\text { become an obstacle if the witness wants to give information without } \\
\text { knowing the time limit for the protection clearly. Of course, there } \\
\text { needs to be a complete and more perfect arrangement, presumably } \\
\text { the right to witness protection needs to be accommodated in } \\
\text { principles, general provisions, types of punishment and other } \\
\text { substances. } \\
\text { Keywords: Time Limit, Witness Protection, LPSK, Criminal Case }\end{array}$ \\
\hline \multicolumn{2}{|c|}{$\begin{array}{l}\text { @ JPHI } 2021 \\
\text { Licensed under the CC } 4.0 . \\
\text { Creative Commons } \\
\text { Attribution-ShareAlike } 4.0 \\
\text { International License }\end{array}$} & $\begin{array}{l}\text { Penelitian ini bertujuan untuk mengetahui batas waktu perlindungan } \\
\text { yang diberikan oleh LPSK secara jelas kepada saksi yang sedang } \\
\text { menjalani proses pemeriksaan dan juga untuk mengetahui apakah } \\
\text { LPSK telah memberikan perlindungan sesuai dengan yang berlaku } \\
\text { sekarang. Jenis penelitian yang digunakan adalah penelitian hukum }\end{array}$ \\
\hline
\end{tabular}




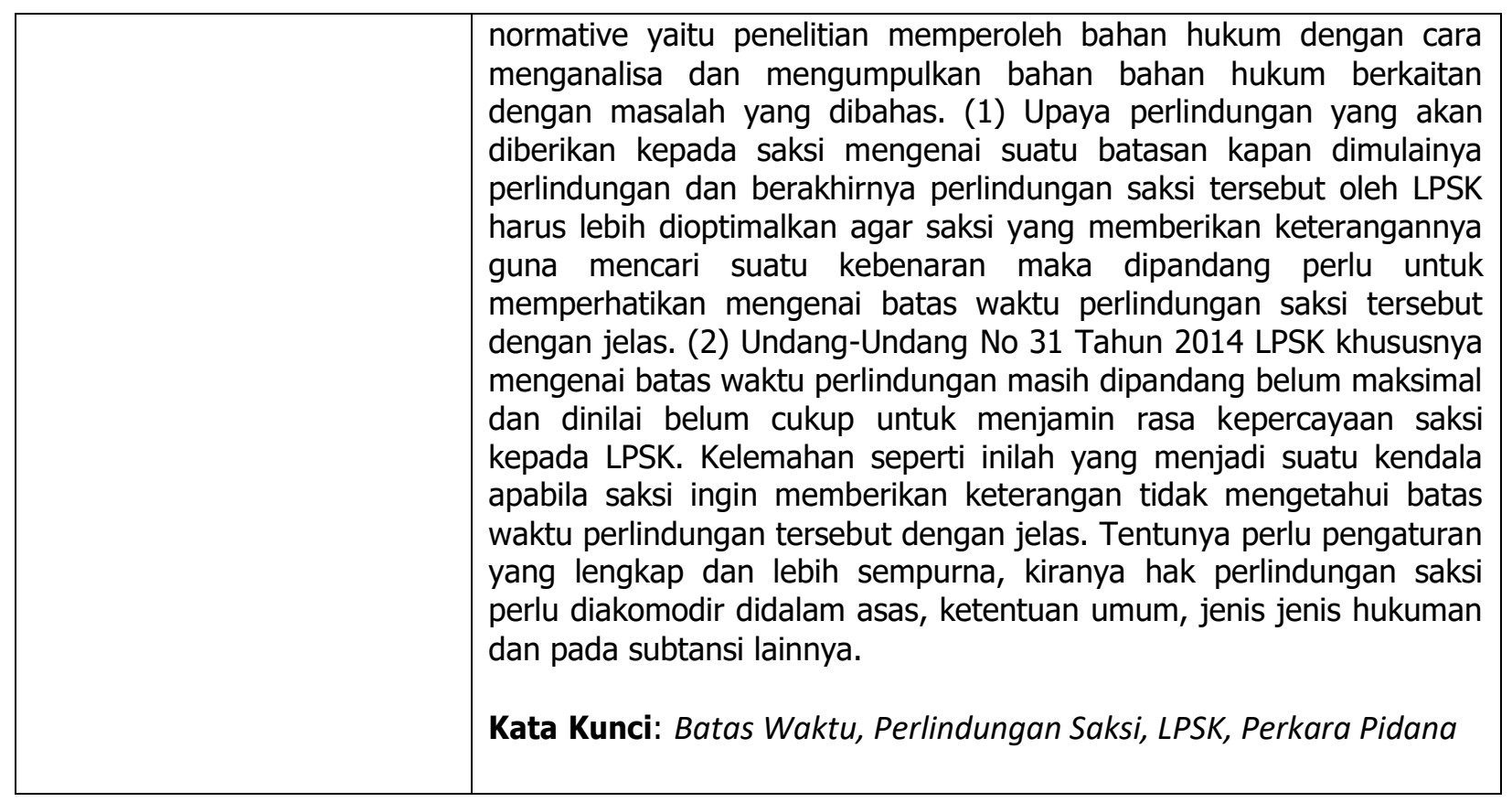

\section{PENDAHULUAN}

Keberhasilan suatu proses peradilan tindak pidana sangat bergantung pada alat bukti yang berhasil diungkap atau diungkapkan oleh saksi. Seperti yang diuraikan Kitab Undang-Undang Hukum Acara Pidana Pasal 184, dimana alat bukti yang sah memiliki kedudukan teratas yaitu Keterangan dari Saksi. Keterangan saksi inilah sebagai alat bukti apa yang dinyatakan saksi dalam persidangan. Keterangan saksi harus lebih dari satu orang saksi agar dapat digunakan sebagai alat bukti ${ }^{1}$.

Hal penting dalam sebuah negara hukum adanya penghargaan dan komitmen untuk menjunjung tinggi HAM serta memberikan jaminan pada warga negara bersamaan dengan kedudukannya dalam hukum (equality before the law) merupakan ciri negara hukum. Bukan hanya tersangka atau terdakwa saja yang perlu dilindungi, tapi saksi juga wajib dilindungi².

Dalam Proses persidangan, yang berkenaan dengan saksi, banyak kasus yang tidak terungkap akibat tidak adanya saksi yang mendukung tugas penegak hukum. Padahal, dengan adanya saksi merupakan unsur yang sangat menentukan dalam penegakan hukum di Indonesia. Keberadaan saksi dalam proses peradilan pidana selama ini kurang mendapat perhatian masyarakat dan penegak hukum. Kasus yang tidak terungkap dan tidak terselesaikan banyak terjadi disebabkan oleh saksi takut

\footnotetext{
${ }^{1}$ Redaksi Bhafana Publishing, Kitab Undang-Undang Hukum Acara Pidana (Jakarta, 2016), p. 234.

${ }^{2}$ Bambang Waluyo, Viktimologi Perlindungan Korban Dan Saksi (Jakarta: Sinar Grafika, 2011).
} 
memberikan keterangan kepada penegak hukum karena mendapat ancaman dari pihak tertentu.

Perlindungan dalam upaya pemenuhan hak dan pemberian bantuan untuk memberikan rasa aman kepada saksi sebagai bagian dari perlindungan masyarakat, dapat diwujudkan dalam berbagai bentuk, seperti melalui pemberian restitusi, kompensasi, pelayanan medis dan bantuan hukum (Soerjono Soekanto. 1984: 133).

Perlindungan saksi dalam proses peradilan pidana di Indonesia belum diatur secara khusus. Pasal 50 sampai dengan Pasal 68 UU No 8 Tahun 1981 tentang hukum acara pidana mengatur perlindungan tersangka dan terdakwa untuk mendapatkan perlindungan dari berbagai kemungkinan pelanggaran HAM. Tidak banyak orang bersedia mengambil resiko untuk melaporkan suatu kejadian pidana jika dirinya, keluarganya, harta bendanya tidak mendapat perlindungan dari ancaman yang mungkin timbul karena laporan yang dilakukan. Begitu juga dengan saksi jika tidak mendapat perlindungan yang memadai. Maka saksi akan menjadi enggan dalam memberikan keterangan sesuai dengan fakta yang dialami, dilihat dan dirasakan.

Peranan saksi sangat penting terutama dalam kejahatan yang dikelompokan pada extraordinary crime dan sebagai salah satu alat bukti yang termuat pada KUHAP. Namun hal ini sangat kontras dengan bentuk perhatian atau perlindungan yang diberikan oleh Negara atau apparat penegak hukum kepada saksi dan korban.

Perlindungan ini berupa perlindungan hukum atau khusus lainnya. Karena nya, sudah saatnya perlindungan saksi diatur dengan Undang-Undang tersendiri. Atas hal tersebut, pemerintah telah menerbitkan Undang-Undang yang khusus mengatur tentang perlindungan saksi yaitu UU No 13 Tahun 2006 Jo UU NO 31 Tahun 2014 tentang LPSK. Undang-Undang ini (lex specialis) memberika syarat dan tata cara pemberian perlindungan dan bantuan untuk saksi yang sebelumnya terbagi dalam beberapa aturan.

Contohnya Undang-Undang Peraturan Pemerintah No 57 tahun 2003 tentang Tata Cara Perlindungan Khusus Bagi Pelapor dan Saksi Tindak Pidana Pencucian Uang (PP. No 57/2003). Undang-Undang No 31 Tahun 2014 tentang LPSK menyebutkan "Dalam rangka menumbuhkan partisipasi masyarakat untuk mengungkap tindak pidana, perlu diciptakan iklim yang kondusif dengan memberikan perlindungan hukum dan keamanan kepada setiap orang yang mengetaui atau menemukan suatu hal yang dapat membantu mengungkapkan tindak pidana yang telah terjadi dan melaporkan hal 
tersebut kepada penegak hukum. Selanjutnya disebut pelapor yang demikian itu harus diberikan perlindungan yang memadai atas laporannya sehingga ia tidak merasa terancam atau teintimidasi baik hak maupun jiwanya.

Didalam Undang-Undang No 31 Tahun 2014 Pasal 8 menyatakan Perlindungan terhadap saksi sebagaimana dimaksud dalam pasal 5 diberikan sejak tahap penyidikan dimulai dan berakhir sesuai dengan ketentuan sebagaimana diaturnya dalam UndangUndang ini. Dalam keadaan tertentu, perlindungan diberikan sesaat setelah permohonan diajukan kepada LPSK.

\section{RUMUSAN MASALAH}

Berdasarkan latar belakang masalah di atas, sehingga dapat dirumuskan suatu rumusan masalah yang diteliti yakni sebagai berikut:

1. Bagaimana cara mengetahui batas waktu perlindungan saksi oleh LPSK dalam perkara pidana?

2. Bagaimana konsekuensi yuridis apabila batas waktu perlindungan saksi tidak diatur dalam Undang-Undang 31 Tahun 2014?

\section{METODE PENELITIAN}

Hukum sebagai salah satu suatu cabang ilmu pengetahuan juga terikat pada paradigma sebagaimana ilmu pengetahuan umumnya. ${ }^{3}$ Paradigma penelitian dalam ilmu hukum merupakan suatu hasil konstelasi dari kerangka pemikiran baik dalam bentuk kajian rasional secara normatif atau doktrinal yang bersifat deduktif maupun empiris yang bersifat induktif. ${ }^{4}$ Jenis penelitian hukum ini merupakan penelitian normatif, yaitu penelitian yang memperoleh bahan hukum dengan cara mengumpulkan dan menganalisa bahan-bahan hukum yang berhubungan dengan masalah yang akan dibahas. Penelitian hukum dilakukan untuk mencari pemecahan atas isu hukum yang timbul, oleh karena itulah, penelitian hukum merupakan suatu penelitian di dalam kerangka know how di dalam hukum. Hasil yang dicapai adalah untuk memberikan preskripsi mengenai apa yang seyogyianya atas isu yang diajukan. ${ }^{5}$ Sifat penelitian ini adalah sifat penelitian

\footnotetext{
3 Yati Nurhayati, 'Perdebatan Antara Metode Normatif Dengan Metode Empirik Dalam Penelitian Ilmu Hukum Ditinjau Dari Karakter, Fungsi, Dan Tujuan Ilmu Hukum', Jurnal Al Adl, Vol 5.Nomor 10 (2013).

${ }^{4}$ M. Yasir Said, Yati Nurhayati, Ifrani, 'Metodologi Normatif Dan Empiris Dalam Perspektif Ilmu Hukum', Jurnal Penegakan Hukum Indonesia, Vol. 2.No. 1 (2021).

${ }^{5}$ Peter Mahmud Marzuki, Penelitian Hukum, Revisi (Jakarta: Prenamedia, 2015).
} 
preskriptif yakni menguji kembali menurut teori hukum terhadap norma yang dianggap masih kabur (vage of norm).

\section{PEMBAHASAN}

\section{Mengetahui Batas Waktu Perlindungan Saksi Oleh LPSK Dalam Perkara Pidana.}

Keberhasilan suatu proses peradilan pidana sangat bergantung pada alat bukti yang berhasil diungkap atau dikemukakan. Dalam proses persidangan, terutama yang berkenaan dengan saksi, banyak kasus yang tidak tertungkap. Padahal adanya saksi merupakan unsur yang sangat menentukan dalam proses peradilan pidana. Perlindungan saksi yang mana pada:

1. Peraturan Pemerintah Republik Indonesia Nomor 2 Tahun 2002 tentang Tata Cara Perlindungan Terhadap Korban dan Saksi dalam Pelanggaran Hak Asasi Manusia Yang Berat.

2. Peraturan Pemerintah Republik Indonesia Nomor 3 Tahun 2002 tentang Kompensasi, Restitusi dan Rehabilitasi Terhadap Korban Pelanggaran Hak Asasi Manusia Yang Berat.

3. Peraturan Pemerintah Republik Indonesia Nomor 24 Tahun 2003 tentang Tata Cara Perlindungan Terhadap Saksi, Penyidik, Penuntut Umum, dan Hakim dalam Perkara Tindak Pidana Terorisme.

4. Peraturan Pemerintah Republik Indonesia Nomor 57 Tahun 2003 tentang Tata Cara Perlindungan Khusus Bagi Pelapor dan Saksi Tindak Pidana Pencucian Uang.

5. Undang-Undang Republik Indonesia Nomor 13 Tahun 2006 tentang Perlindungan Saksi Korban.

6. Kemudian, Undang-Undang Republik Indonesia Nomor 31 Tahun 2014. Pada Undang-Undang ini memberikan perlindungan pada saksi dalam semua tahap proses peradilan pidana dalam lingkungan peradilan. Perlindungan saksi tertujuan memberikan rasa aman kepada saksi guna memberikan keterangan dalam proses peradilan pidana. Perlindungan dan hak saksi tersebut diberikan sejak tahap penyidikan dimulai dan 
berakhirnya sesuai ketentuan. LPSK bertanggung jawab menangangi pemberian perlindungan dan bantuan pada saksi berdasarkan tugas dan kewenangan ${ }^{6}$.

Lembaga Perlindungan Saksi dan Korban dibentuk berdasarkan Undang-Undang No 13 Tahun 2006 tentang LPSK mempunyai peran yang penting dalam rangka mewujudkan penegakan hukum dan antisipasi pelanggaran hak asasi manusia. Perkembangan sistem peradilan pidana, tidak saja berorientasi kepada pelaku saja, melainkan juga berorientasi untuk kepentingan saksi. Oleh sebab itu, Lembaga LPSK harus dikembangkan dan diperkuat agar dalam menjalankan tugas, fungsi dan kewenangannya dapat sinergis dengan tugas. fungsi, dan kewenangan Lembaga penegak hukum yang berada dalam sistem peradilan pidana. Selain saksi terdapat pihak lain yang memiliki kontribusi besar untuk mengungkap tindak pidana tertentu, yaitu saksi pelaku (Justice Collaborator), Pelapor (Whistle Blower) dan ahli, termasuk juga orang dapat memberikan sebuah keterangan yang berkaitan dengan suatu perkara pidana meskipun tidak ia dengan sendiri, tidak ia lihat sendiri dan tidak ia alami sendiri, sepanjang keterangan orang itu berhubungan dengan tindak pidana, sehingga terhadap mereka perlu diberikan Perlindungan.

Tindak pidana tertentu seperti pelanggaran ham berat, korupsi, pencucian uang, teorisme, perdagangan orang, narkotika, psikotropika, tindak pidana seksual terhadap anak, dan tindak pidana yang mengakibatkan saksi dihadapkan dengan situasi yang cukup membahayakan jiwanya. Saksi berhak memperoleh bantuan biaya sementara sampai batas waktu perlindungan berakhir. Perlindungan terhadap saksi diberikan sejak tahap penyelidikan dimulai dan berakhir. LPSK mempunyai suatu kekosongan hukum, mengenai tidak diaturnya suatu batasan perlindungan kepada saksi secara jelas. Mengakibatkan keberadaan saksi yang ingin memberikan keterangan didalam persidangan, mengalami kesulitan dikarenakan tidak bisa menghadirkan saksi disebabkan adanya ancaman, baik fisik maupun psikin dari pihak tertentu?

Penyelidikan merupakan proses utama dalam hukum acara pidana, tujuan dari dilaksanakan penyelidikan ini guna untuk menghindari kesewenang-wenangan dalam proses hukum acara pidana sebagai mana pada era HIR dimana tidak jelas batas-batas

\footnotetext{
${ }^{6}$ Undang-Undang Republik Nomor 13 Tahun 2006 Tentang Perlindungan Saksi Dan Korban.

7 Undang-Undang Republik Indonesia Nomor 31 Tahun 2014 Tentang Perlindungan Saksi Dan Korban.
} 
antara pengusutan dan penyidika ${ }^{8}$. KUHAP memberi definisi penyelidikan sebagai "serangkaian Tindakan penyelidikan untuk mencari dan menemukan suatu peristiwa yang diduga sebagai tindak pidana guna menentukan dapat atau tidaknya dilakukan penyidikan ${ }^{9}$. Tujuan utama dari penyelidian ialah untuk menentukan apakah suatu peristiwa dapat dilanjutkan ke tahap tingkatan penyidikan atau tidak. Syarat agar dapat dilanjutkan ketingkat penyidikan adalah peristiwa tersebut merukapakan suatu tindak pidana ${ }^{10}$. Rangkaian Tindakan penyelidikan berupa, pengolahan tempat kejadian perkara (TKP), pengamatan (observasi), wawancara (interview), pembuntutan (surveillance), penyamaranm (undercover), pelacakan (tracking) dan analisis dokumen) $)^{11}$.

Perlindungan terhadap saksi diberikan sejak tahap penyelidikan, dimana pada tahap ini berlangsung berdasarkan kriteria tingkat kesulitan perkara yang ditemukan pada Peraturan Kepala Kepolisian Negara Republik Indonesia Nomor 14 Tahun 2012 tentang Manajemen Penyidikan Tindak Pidana.

Dimana proses penyelidikan dibagi menjadi 4 macam, yaitu perkara mudah, sedang, sulit dan sangat sulit. Pada tahap penyidikan ini Peraturan Kapolri Nomor 12 Tahun 2009 mengatur batas waktu penyelesaikan perkara yaitu Perkara mudah 30 hari, sedang 60 hari, sulit 90 hari dan perkara sangat sulit 120 untuk penyidikan. Setelah terbitnya Peraturan Kapolri Nomor 14 Tahun 2012 yang menghapus Perkap Nomor 12 Tahun 2009 maka tidak ada lagi batasan waktu untuk menindaklanjuti laporan dan batas waktu menyelesaian perkara tersebut. Tetapi dalam Perkap No 14 Tahun 2014 tentang Manajemen Penyidikan Tindak Pidana yang menggantikan Perkap No 12 Tahun 2009 tentang Pengawasan dan Pengendalian Penanganan Perkara Pidana di Lingkungan Polri.

Akan tetapi penyelidik dan penyidik wajib menentukanwaktu yang diperlukan dalam pelaksanaan kegiatan penyelidikan dan penyidikan didalam perencanaan penyelidikan dan penyidikan (Pasal 16 ayat (2) huruf $f$ dan Pasal 17 ayat (2) Perkap No. 14 Tahun 2012). Gelar perkara yang dilakukan pada tahap awal penyidikan juga harus menentukan target waktu (Pasal 70 ayat (2) huruf e Perkap No. 14 Tahun 2012) (Penyelesaian Perkara Di Kepolisian).

\footnotetext{
${ }^{8}$ Tolib Effendi, Dasar-Dasar Hukum Acara Pidana (Malang: Setara Press, 2014).

${ }^{9}$ Andi Hamzah, Hukum Acara Pidana Indonesia (Jakarta: Sinar Grafika, 2008).

${ }^{10}$ Tolib Effendi.

${ }^{11}$ Tolib Effendi.
} 
Rangkaian tindakan penyidikan, didalam KUHAP hanya menyebutkan bahwa penyidikan adalah serangkaian tindakan penyidik, apabila ditafsirkan secara sistematis dengan tugas dan fungsi penyidik yang ada didalam KUHAP tentunya masih kurang kongkrit. Namun, didalam Perkap Nomor 14 Tahun 2012 tentang Manajemen Penyidikan Tindak Pidana, khususnya didalam Pasal 4 dan Pasal 15 mengatur tentang dasar dilakukannya penyidikan dan tahapan kegiatan penyidikan atau dapat dikatakan rangkaian tindakan. Penyelidikan dan penyidikan tidak dapat terpisahkan namun keduanya berbeda dan merupakan tahapan, sehingga untuk menguraikan rangkaian tahapan penyidikan akan dimulai dari yang pertama Surat Pemberitahuan Dimulainya Penyidikan(SPDP), yang kedua Upaya Paksa. Upaya paksa ini terdiri dari pemanggilan, penagkapan dan penahanan, penggeledahan dan penyitaan, ketiga Pemeriksaan, keempat Gelar Perkara pada Pasal 70 ayat (2) Perkap No 14 Tahun 2012 menyebutkan bahwa gelar perkara biasa dilaksanakan pada tahap awal proses penyidikan, dan akhir proses penyidikan. Gelar Perkara pada tahap awal, pertengahan dan perkara khusus, kelima Pemyelesaian Berkars Perkara, keenam Pelimpahan Perkara ke Penuntut Umum dan terakhir Pengentian Penyidikan.

Jangka waktu penahanan ditingkat penyidikan, pihak yang berwenang ialah penyidik yang dapat diperpanjang oleh penuntut umum terdapat pada Pasal 24 ayat (1) dan ayat (2) KUHAP, yang mana jangka waktu untuk penahanan 20 hari dan dapat diperpanjang oleh penuntut umum sampai dengan 40 hari menjadi 60 hari maksimal masa penahanan.

Kemudian dilanjutkan ke tahap penuntutan, menurut Pasal 1 angka 7 KUHAP penuntutan adalah tindakan penuntut umum untuk melimpahkan perkara pidana ke pengadilan negeri yang berwenang dalam hal dan menurut cara yang diatur dalam Undang - Undang ini dengan permintaan supaya diperiksa dan diputus oleh hakim di sidang pengadilan. Penuntutan adalah tindakan penuntut umum yang artinya yang berwenang untuk melakukan penuntutan adalah penuntut umum saja ${ }^{12}$. Seperti halnya penyelidikan yang hanya merupakan kewenangan pejabat POLRI. Adanya prinsip legalitas yang berlandaskan the rule of law dan supremasi hukum, aparat penegak hukum tidak dibenarkan bertindak diluar ketentuan hukum, atau undue to law maupun undue process, bertindak sewenang-wenang atau abuse of power.

${ }^{12}$ Pasal 137, Kitab Undang-Undang Acara Pidana. 
Jangka waktu penahanan ditingkat penuntutan, pihak yang berwenang ialah penuntut umum terdapat pada Pasal 25 ayat (1) dan ayat (2) KUHAP, yang mana jangka waktu untuk penahanan 20 hari dan dapat diperpanjang oleh Ketua Pengadilan Negeri sampai dengan 30 hari menjadi 50 hari maksimal masa penahanan.

Dilanjutkan pada tahap pemeriksaan persidangan, pada tahap ini hasil penyidikan yang dikonkritkan dalam bentuk surat dakwaan ditingkat penuntutan akan diuji untuk memperoleh kebenaran materill. Proses pemeriksaan persidangan adalah pembuktian, dimana dialam pembuktian tersebut alat bukti akan dinilai majelis hakim untuk memperoleh kesimpulan. Pada prinsipnya KUHAP mengatur tiga bentuk acara pemeriksaan berdasarkan berat dan ringannya perkara yang diperiksa.

Tiga bentuk acara pemeriksaan tersebut adalah acara pemeriksaaan biasa, cepat dan singkat. Ditahap pemeriksaan persidangan inilah, proses pembuktian berjalan dimana sebuat keterangan saksi sangat diperlukan. Jangka waktu penahanan ditingkat pemeriksaan di Pengadilan Negeri, pihak yang berwenang ialah hakim terdapat pada Pasal 26 ayat (1) dan ayat (2) KUHAP.

Jangka waktu untuk penahanan 30 hari dan dapat diperpanjang oleh Ketua Pengadilan Negeri sampai dengan 60 hari menjadi 90 hari maksimal masa penahanan. Jangka waktu penahanan ditingkat pemeriksaan di Pengadilan Tinggi, pihak yang bewenang ialah Hakim Pengadilan Tinggi terdapat pada Pasal 27 ayat (1) dan ayat (2) KUHAP, yang mana jangka waktu untuk penahanan 30 hari dan dapat diperpanjang oleh Ketua Pengadilan Tinggi sampai dengan 60 hari menjadi 90 hari maksimal masa penahanan. Kemudian, jangka waktu penahanan ditingkat pemeriksaan di Pengadilan Tingkat Kasasi, pihak yang berwenang ialah Hakim Mahkamah Agung terdapat pada Pasal 28 ayat (1) dan ayat (2) KUHAP, yang mana jangka waktu untuk penahanan 50 hari dan dapat diperpanjang oleh Ketua Mahkamah Agung sampai dengan 60 hari menjadi 110 hari maksimal masa penahanan.

Salah satu upaya lindungan yang dberikan LPSK ialah "memperoleh perlindungan atas keamanan pribadi, keluarga, dan harta barangnya, serta lolos dari ancaman yang berkenaan dengan kesaksian akan, sedang, atau telah diberikan. Secara khusus mengenai batas waktu perlindungan saksi oleh LPSK tersebut dimungkinan bersifat transparan mengingat selama ini orang tidak mau menjadi saksi karena akan membahayakan jiwa saksi yang mendapatkan ancaman dari berbagai kejahatan yang disaksikan. Akan tetapi dimungkinkan agar pengaturan untuk mengetahui batas 
waktu perlindungan diatur secara khusus didalam Undang-Undang 31 Tahun 2014 tentang Lembaga Perlindungan Saksi dan Korban agar semakin banyak saksi yang akan berhadir ataupun ingin memberikan kesaksiannya guna mempercepat untuk mengungkap suatu kejahatan.

Oleh karena itu mengenai batas waktu diberlakukan untuk keamanan diri, pihak keluarga, dan benda barang, serta lolos dari ancaman berkenaan dengan kesaksian akan, sedang atau telah diberikan oleh saksi tersebut. Dengan diadakannya batasn waktu mengenai perlindngan saksi, keuntungan yang didapat ialah berupa rasa kepastian yang terjamin mendapatkan perlindungan tersebut, diberikannya suatu pembatasan secara transparan guna mengantisipasi ancaman yang akan datang kepada saksi agar wujud perlindungan yang diberikan oleh LPSK bekerja secara penuh karena diadakannya batasan waktu.

\section{Konsekuensi Yuridis Apabila Batas Waktu Perlindungan Saksi Tidak Diatur Dalam Undang-Undang 3I Tahun 2014.}

Hal penting dalam negara hukum adalah adanya penghargaan dan komitmen menjunjung tinggi hak asasi manusia serta jaminan semua warga negara bersamaan kedudukannya di dalam hukum (equality before the law). Pasal 27 ayat (1) Undang Undang 1945 menegaskan: "Segala warga negara bersamaan kedudukannya di dalam hukum dan pemerintahan dan wajib menjunjung hukum dan pemerintahan itu dengan tidak ada kecualinya." Prinsip demikian idealnya bukan hanya sekedar tertuang didalam Undang - Undang Dasar 1945 dan perundang - undangan. Namun yang lebih utama dan terutama adalah dalam pelaksanaan atau implementasinya ${ }^{13}$.

Hukum perlindungan saksi diperlukan applied theory yaitu teori Hukum Acara Pidana terutama teori hukum pembuktian dan sistem peradilan pidana. Kebutuhan masyarakat yang besar akan keamanan umum, sebagai stuatu kebutuhan akan perdamaian dan ketertiban telah mendikte perkembangan awal hukum, telah mendorong manusia untuk mencari sesuatu dasar yang pasti berupa aturan yang mengatur tindak manusia yang dapat menghalangi individu, yang akhirnya dapat mendirikan suatu masyarakat yang teguh dan mantap. Tekanan kepentingan masyarakat tidak begitu mendesak, namun ada kebutuhan untuk menyesuaikan dengan kebutuhan-kebutuhan di

${ }^{13}$ Bambang Waluyo, Viktimologi Perlindungan Korban \& Saksi (Jakarta: Sinar Grafika, 2018). 
bidang keamanan umum dan membuat kompromi - kompromi baru secara terus menerus dalam masyarakat karena terjadinya perubahan dan untuk itu diperlukan penyesuaianpenyesuaian.

Oleh karena itu selalu dirasakan adanya keperluan untuk mengadakan perubahanperubahan kaidah hukum dan menyesuaikannya dengan keadaan, sehingga hasilnya terdapat suatu hukum yang sempurna. Setiap negara didunia ini memiliki tata hukum atau hukum positif untuk memelihara dan mempertahankan keamanan, ketertiban dan ketentraman bagi setiap warga negaranya atau orang yang berada dalam wilayahnya.

Hal inilah yang mendasari perlunya negara mengatur masalah perlindungan saksi sebagai bagian dari pengimplementasian tujuan nasional untuk mensejahterakan masyarakat Indonesia, adanya perlindungan segenap kepentingan bangsa Indonesia, keikut sertaan dalam melaksanakan ketertiban dunia dalam hubungannya dengan dunia internasional sebagaimana yang diamanatkan dalam alenia keempat Pembukaan UndangUndang 1945.

Semua aspek perlindungan saksi harus didasarkan pada apa yang telah digariskan dalam Undang-Undang Dasar 1945 sebagai hukum dasar untuk operasionalisasi dan pengaturan tugas-tugas aparatur di bidang penegakkan hukum. Peranan saksi dalam setiap persidangan perkara pidana sangat penting karena kerap keterangan saksi dapat mempengaruhi dan menentukan kecenderungan keputusan hakim. Seorang saksi dianggap memiliki kemampuan yang dapat menentukan kemana arah keputusan hakim. Hal ini memberikan efek kepada setiap keterangan saksi selalu mendapat perhatian yang sangat besar baik oleh pelaku hukum yang teribat di dalam persidangan maupun oleh masyarakat pemerhati hukum. Oleh karena itu saksi sudah sepatutnya diberikan perlindungan hukum karena dalam mengungkap suatu tindak pidana saksi secara sadar mengambil resiko dalam mengungkap kebenaran materiil.

Selanjutnya dalam memberikan laporan ataupun kesaksian dalam mengungkap adanya indikasi suatu tindak pidana korupsi, maka si pelapor maupun saksi kedudukannya dilindungi oleh Undang-Undang, jadi tidak perlu khawatir untuk menginformasikan atau melaporkan setiap temuan atau bukti-bukti yang mengarah pada adanya suatu tindak pidana korupsi kepada aparat penegak hukum.

Selama ini dalam proses peradilan pidana keberadaan saksi dan korban hanya diposisikan sebagai pihak yang dapat memberikan keterangan, dimana keterangannya dapat dijadikan alat bukti dalam mengungkap sebuah tindak pidana, sehingga dalam hal 
ini yang menjadi dasar bagi aparat penegak hukum yang menempatkan saksi dan korban hanya sebagai pelengkap dalam mengungkap suatu tindak pidana dan memiliki hak - hak yang tidak banyak diatur dalam KUHAP, padahal untuk menjadi seorang saksi dalam sebuah tindak pidana, tentunya keterangan yang disampaikan tersebut dapat memberatkan atau meringankan seorang terdakwa, yang tentunya bagi terdakwa apabila keterangan seorang saksi dan korban tersebut memberatkan tersangka/terdakwa, maka ada kecenderungan terdakwa menjadikan saksi dan korban tersebut sebagai musuh yang telah memberatkannya dalam proses penanganan perkara, hal ini tentunya dapat mengancam keberadaan saksi dan korban. Berdasarkan hal tersebut,maka tentunya seorang saksi dan korban perlu mendapatkan perlakuan dan hak-hak khusus, karena mengingat keterangan yang disampaikan dapat pengaturan yang tegas dan jaminan keamanan bagi seorang saksi, maka seseorang akan merasa takut untuk menjadi seorang saksi. Kedepannya diharapkan supaya diberikan jaminan keamanan dan keselamatan bagi seorang saksi, agar masyarakat dapat berperan penting dalam mengungkap sebuah tindak pidana, seperti menjadi seorang saksi, karena tanpa adanya jaminan keamanan dan keselamatan yang diberikan kepada seorang saksi, maka masyarakat enggan atau bahkan tidak mau menjadi seorang saksi, padahal keberadaan seorang saksi dalam mengungkap suatu tindak pidana sangat penting.

Dalam usahanya mengatur, hukum menyesuaikan kepentingan perorangan dengan kepentingan masyarakat dengan sebaik-baiknya: berusaha mencari keseimbangan antara memberi kebebasan kepada individu dan melindungi masyarakat terhadap kebebasan individu. Mengingat bahwa masyarakat itu terdiri dari individuindividu yang menyebabkan terjadinya interaksi, maka akan selalu terjadi konflik atau ketegangan antara kepentingan perorangan dan antara kepentingan perorangan dengan kepentingan masyarakat. Hukum berusaha menampung ketegangan atau konflik ini sebaik-baiknya. Hukum sebagai kumpulan peraturan atau kaidah mempunyai isi yang bersifat umum dan normatif. Umum karena berlaku bagi setiap orang lain dan normatif karena menentukan apa yang seyogianya dilakukan, apa yang tidak boleh diakukan atau harus dilakukan serta menentukan bagaimana caranya melaksanakan kepatuhan pada kaidah-kaidah ${ }^{14}$.

${ }^{14}$ Sudikno Mertokusumo, Mengenai Hukum Suatu Pengantar (Yogyakarta: Cahaya Atma Pustaka, 2019). 
Hak itu memberi kenikmatan dan keleluasaan kepada individu dalam melaksanakannya, sedangkan kewajiban merupakan pembatasan dan beban, sehingga yang menonjol ialah segi aktif dalam hubungan hukum itu, yaitu hak. Kita lihat juga bahwa yang pada umumnya ditonjolkan adalah hak - hak asasi, sedangkan mengenai kewajiban - kewajiban asasi dapatlah dikatakan tidak pernah disebut -sebut. Hak - hak asasi seorang terdakwa selalu mendapat perhatian, selalu ditonjolkan, selalu diperjuangkan, tetapi sebaliknya kewajiban asasinya terhadap masyarakat boleh dikatakan tidak pernah disinggung. Dalam usaha pembangunan hukum nasional kewajiban asasi warga negara mendapat perhatian dalam TAP MPR NO. IIMPR/1983 tentang Garis - Garis Besar Haluan Negara.

Hak dan kewajiban bukanlah merupakan kumpulan peraturan atau kaidah, melainkan merupakan pertimbangan kekuasaan dalam bentuk hak individual di satu pihak yang tercermin pada kewajiban pada pihak lawan. Kalau ada hak maka ada kewajiban. Hak dan kewajiban ini merupakan kewenangan yang diberikan kepada seseorang oleh hukum. Hak adalah kepentingan yang dilindungi hukum, sedangkan kepentingan adalah tuntutan perorangan atau kelompok yang diharapkan untuk dipenuhi. Kepentingan pada hakikatnya mengandung kekuasaan yang dijamin dan dilindungi oleh hukum dalam melaksanakannya ${ }^{15}$.

Perlindungan-perlindungan terhadap saksi dan korban sejatinya tidak secara khusus diatur didalam KUHAP maupun KUHP. Sedangkan banyak sekali ancaman yang timbul terhadap saksi dan korban dalam sebuah tindak pidana, dari mulai ancaman verbal, fisik, intimidasi, teror, hingga pembunuhan. Oleh karena itu, Undang-Undang Nomor 31 Tahun 2014 mencoba menunjung hak-hak dari saksi dan korban. Hak tersebut terkait pula dengan penegakan hak asasi manusia sebagaimana tercantum di dalam konstitusi Undang-Undang Pasal 28G, 28I, dan 28H.

Hak-hak yang diberikan oleh Undang-Undang Nomor 31 Tahun 2014 terhadap saksi dan korban adalah memperoleh perlindungan atas keamanan pribadi, keluarga, dan harta bendanya, serta bebas dari ancaman yang berkenaan dengan kesaksian yang akan, sedang, atau telah diberikannya; ikut serta dalam proses memilih dan menentukan bentuk perlindungan dan dukungan keamanan; memberikan keterangan tanpa tekanan; mendapat penerjemah; bebas dari pertanyaan yang menjerat; mendapatkan informasi

${ }^{15}$ Sudikno Mertokusumo. 
mengenai perkembangan kasus; mendapatkan informasi mengenai putusan pengadilanl; mengetahui dalam hal terpidana dibebaskan; mendapatkan identitas baru; mendapatkan tempat kediaman baru; memperoleh penggantian biaya transportasi sesuai dengan kebutuhan mendapat nasihan hukum; dan / atau memperoleh bantuan biaya hidup sementara sampai batas waktu perlindungan berakhir ${ }^{16}$.

Pengaturan mekanisme perlindungan saksi yang tercantum didalam beberapa peraturan perundang-undangan diharapkan pada saksi untuk memahami hak-haknya dan prosedur pemenuhannya. Demikian pula untuk pemerintah, penegak hukum, LPSK, dan pihak-pihak yang terkait agar proporsional dan profesional dalam melaksanakan perundang-undangan tersebut. Upaya yang efektif adalah pemahaman yang menyeluruh diantaranya melalui sosialisasi, mengingat regulasi perlindungan saksi dan eksistensi LPSK itu sendiri relatif masih baru. Terpenuhinya dan terlaksananya perlindungan secara baik, cepat dan akuntabel banyak dipengaruhi oleh kesiapan, keseriusan, serta profesionalitas aparat dan lembaga yang mengemban tugas perlindungan.

Bagi saksi yang berhak mendapat suatu perlindungan seringkali masih belum memahami hak-hak yang tercantum dalam perundang-undangan. Apabila perlindungan dapat dilakukan secara baik, juga berdampak positif bagi terselenggaranya proses peradilan pidana. Undang-Undang 31 Tahun 2014 menegaskan, bahwa adanya saksi merupakan unsur yang sangat menentukan dalam prsoes peradilan pidana. Keberadaan saksi dalam proses peradilan pidana selama ini kurang mendapat perhatian masyarakat dan penegak hukum. Banyak kasus-kasus yang tidak terungkap dan tidak terselesaikan banyak disebabkan oleh saksi yang takut memberikan kesaksian kepada penegak hukum karena mendapat ancaman dari pihak tertentu.

Dengan lahirnya Undang-Undang 31 Tahun 2014 adalah salah satu faktor penting dalam menunjang sistem peradilan pidana yang baik. Sistem peradilan pidana yang terintegrasi adalah tiang dari penegakan hukum pidana, seperti sinkronisasi komponen peradilan pidana dan pengawasam serta pengendalian karena keberhasilan sistem peradilan pidana disuatu negara dapat dilihat dari rendahnya tingkat kriminalitas yang terjadi. Salah satu bukti sistem peradilan pidana yang baik adalah perlindungan terhadap saksi dan korban. Perlindungan tersebut semata-mata adalah pembuktian negara Indonesia sebagai negara hukum yang menjungjung tinggi hak asasi manusia.

${ }^{16}$ Pasal 5 Ayat (1) Undang-Undang 31 Tahun 2014. 
Didalam amanat Pancasila sila kedua diamanatkan mengenai Kemanusiaan yang adil dan berdaba sebagai refleksi dalam perlindungan hak asasi manusia dalam lembaga peradilan Indonesia. Saat ini bahkan setelah amandemen Undang-Undang Dasar 1945 telah banyak memasukkan perlindungan hak-hak asasi manusia sebagai bagian dari hak konstitusi. Bahkan sebelumnya juga telah ada Undang-Undang Nomor 39 Tahun 1999 tentang Hak Asasi Manusia. Diberlakukannya Undang-Undang Nomor 31 Tahun 2014 tentang Perlindungan Saksi dan Korban, masih dipandang belum maksimal. UndangUndang Perlindungan Saksi dan Korban dinilai belum cukup untuk menjamin perlindungan saksi dan korban yang secara langsung memperhambat kinerja dari LPSK itu sendiri.

Salah satunya yaitu, Undang - Undang Perlindungan Saksi dan Korban inibelum secara khusus mengatur mengenai wewenang seperti apakah yang dimiliki oleh LPSK dalam rangka pemberian perlindungan terhadap saksi dan korban. Kelemahan kelemahan perlindungan saksi dan korban dapat dilihat dari berbagai macam perspektif. Dapat dilihat dari sisi aparat penegak hukum, aturan perundang - undangan, budaya masyarakat, lembaga penegakan dan yang lebih penting mengenai batas waktu perlindungan tersebut.

Jika direduksi kembali, faktor terpenting dalam penegakan hukum adalah pencapaian tujuan hukum yang diartikan sebagai upaya mewujudkan ketertiban (order). Tujuan ini sejalan dengan fungsi utama hukum, yaitu mengatur. Kebutuhan akan ketertiban merupakan fakta dan kebutuhan objektif bagi setiap masyarakat manusia. Para penganut teori hukum pun menyatakan bahwa kepastian hukum sebagai tujuan dari hukum.

Menurut anggapan mereka, ketertiban atau keteraturan, tidak mungkin terwujud tanpa adanya garis-garis perilaku kehidupan yang pasti. Keteraturan hanya aka nada jika ada kepastian dan untuk adanya kepastian hukum haruslah dibuat dalam bentuk hukum yang pasti pula (tertulis) ${ }^{17}$.

Dengan adanya Undang-Undang Nomor 31 Tahun 2014 terutama mengenai pasal 8 tentang batas waktu perlindungan bagi saksi yang mana bentuk aturan yang kurang memadai dalam penegakan sistem peradilan pidana. Undang - Undang tersebut kurang mampu untuk mengatasi permasalahan-permasalahan perlindungan saksi mengakibatkan

${ }^{17}$ Mochtar Kusumaatmadja, Fungsi Dan Perkembangan Hukum Dalam Pembangunan Nasional (Bandung: Bina Cipta). 
adanya suatu kekosongan hukum. Undang-Undang sebagai sumber hukum yang memiliki peranan penting dalam sistem peradilan pidana harus benar-benar memiliki rumusan yang baik dan efektif. Tidak akan terjadi perlindungan yang efektif apabila tidak didukung dengan Undang-Undang yang baik dan berintegrasi. Secara garis besar batas waku perlindungan saksi didalam pasal 8 memang sudah diatur, tetapi keefektifan dalam perwujudan hal tersebut masih kurang lengkap dalam penjabaran tentang batas waktu perlindungan saksi tersebut.

\section{PENUTUP}

\section{Kesimpulan}

1. Mengetahui Batas Waktu Perlindungan Saksi Oleh LPSK Dalam Perkara Pidana berdasarkan hasil penelitian ini yaitu bahwa keberadaan saksi didalam tiap-tiap acara pemeriksaan selalu dibutuhkan dan keberadaan saksi itu lah memberikan sebuah keseharusan untuk mendapatkan perlindungan yang diberikan oleh pemerintah guna mengingat bahwa saksi adalah orang yang dapat memberikan keterangan guna kepentingan penyidikan, penuntutan dan peradilan tentang suatu perkara yang ia dengan sendiri, ia lihat sendiri dan ia alami sendiri. Dengan demikian dapat dipahami bahwa keberadaan saksi merupakan suatu elemen yang kuat yang sangat menentukan dalam proses peradilan. Oleh karena itu sumber daya manusia yaitu aparatur penegak hukum harus bekerja lebih optimal agar keberadaan saksi mendapat perlindungan, sistem pengegakkan hukum dan peraturan perundangundangan yang mengaturnya. Mengingat pemenuhan hak-hak saksi yang melekat harus berjalan dengan efektif dan kondusif dalam sistem peradilan pidana. Yang mana perlindungan saksi pada tingkat penyidikan mendapatkan perlindungan 20 hari hingga mencapai batas maksimal 60 hari, pada tingkat penuntutan mendapatkan perlindungan 20 hari hingga mencapai batas maksimal 50 hari, pada tingkat pengadilan negeri mendapatkan perlindungan 30 hari hingga mencapai batas maksimal 90 hari, pada tingkat pengadilan tinggi mendapatkan perlindungan 30 hari hingga mencapai batas maksimal 90 hari, kemudian pada tingkat mahkamah agung mendapatkan perlindungan 50 hari hingga mencapai batas maksimal 110 hari.

2. Konsekuensi Yuridis Apabila Batas Waktu Perlindungan Saksi Tidak Diatur 
Dalam Undang-Undang Nomor 13 Tahun 26 Jo Undang-Undang Nomor 31 Tahun 2014 berdasarkan hasil penelitian ini yaitu kehadiran Undang-Undang Nomor 31 Tahun 2014 khususnya mengenai batas waktu perlindungan saksi masih dipandang belum maksimal dan dinilai belum cukup untuk menjamin rasa kepercayaan saksi kepada LPSK mengingat apabila tidak dijalankan dengan baik oleh aparat penegak hukum maka akan timbul ketidakpastian hukum. Kelemahan seperti inilah yang menjadi suatu kendala apabila saksi yang ingin memberikan keterangan tidak mengetahui batas waktu perlindungan tersebut dengan jelas. Tentunya perlu pengaturan yang lengkap dan lebih sempurna, kiranya hak perlindungan saksi perlu untuk diakomodir didalam asas, ketentuan umum, jenis-jenis hukuman dan pada subtansi lainnya

\section{Saran}

1. Hendaknya mengenai suatu batas waktu perlindungan saksi direvisi kembali agar pengaturan mengenai batasan waktu dapat berjalan dengan maksimal dimana dibutuhkannya peningkatan pengetahuan kepada para penegak hukum guna meningkatkan kesadaran saksi pada tingkat penyidikan, penuntutan dan tingkat peradilan.

2. Hendaknya didalam Undang-Undang Nomor 31 Tahun 2014 Lembaga Perlindungan Saksi dan Korban direvisi kembali dan perlu ditambahkan mengenai pasal khusus tentang perlindungan batas waktu, untuk diaturnya suatu batas waktu tentang perlindungan saksi secara jelas agar setiap orang yang merupakan saksi dapat mengetahui perlindungan dirinya sendiri ataupun keluarganya sendiri terutama pada UU No. 31 Tahun 2014 Pasal 8. Hal terpenting dalam pengaturan tersebut adalah aplikasi secara objektif, transparan, dan akuntabel serta mengutamakan pelayanan.

\section{Buku}

\section{DAFTAR PUSTAKA}

Hamzah. Andi. 2008. Hukum Acara Pidana Indonesia, Jakarta: Sinar Grafika.

Tiena Masriani. Yulies. 2004. Pengantar Hukum Indonesia, Jakarta: Sinar Grafika.

Waluyo. Bambang. 2011. Viktimologi Perlindungan Korban dan Saksi, Jakarta: Sinar Grafika. 
Effendi. Tolib. 2014. Dasar - Dasar Hukum Acara Pidana, Malang: Setara Press.

Nurhayati, Y. 2013. Perdebatan Antara Metode Normatif Dengan Metode Empirik Dalam Penelitian Ilmu Hukum Ditinjau Dari Karakter, Fungsi, dan Tujuan IlmuHukum. Jurnal Al Adl, Vol. 5, No. 10.

Nurhayati, Y., Ifrani, M.Y. Said. 2021. Metodologi Normatif dan Empiris Dalam Perspektif Ilmu Hukum. Jurnal Penegakan Hukum Indonesia, Vol. 2, No.1, February 2021.

Marzuki Peter Mahmud. (2015). Penelitian Hukum Edisi Revisi. Jakarta: Prenadamedia.

Mertokusumo. Sudikmo. 2019. Mengenal Hukum Suatu Pengantar, Yogyakarta: Cahaya Atma Pustaka.

Kusumaatmadja. Mochtar. 1970. Fungsi dan Perkembangan Hukum dalam Pembangunan Nasional, Bandung: Fakultas Hukum Universitas Pedjadjaran

\section{Peraturan Perundang-Undangan}

Undang-Undang Dasar 1945.

Kitab Undang - Undang Hukum Acara Pidana.

Peraturan Pemerintah Republik Indonesia Nomor 2 Tahun 2002 tentang Tata Cara Perlindungan Terhadap Korban dan Saksi dalam Pelanggaran HAM yang berat.

Peraturan Pemerintah Republik Indonesia Nomor 3 Tahun 2002 tentang Kompensasi, Restitusi dan Rehabilitasi terhadap Korban Pelanggaran HAM yang berat.

Peraturan Pemerintah Republik Indonesia Nomor 24 Tahun 2003 tentang Tata Cara Perlindungan terhadap Saksi, Penyidik, Penuntut Umum, dan Hakim dalam perkara pidana,

Peraturan Pemerintah Republik Indonesia Nomor 57 Tahun 2003 tentang Tata Cara Perlindungan Khusus Bagi Pelapor dan Saksi Tindak Pidana Pencucian Uang.

Undang-Undang Republik Indonesia Nomor 13 Tahun 2006 tentang Perlindungan Saksi dan Korban.

Undang-Undang Republik Indonesia Nomor 31 Tahun 2014 tentang Perlindungan Saksi dan Korban.

Peraturan Kapolri Nomor 14 Tahun 2012. 
